\title{
Does More Trade Potential Remain in Arab States of the Gulf ?
}

\author{
Ruhul A Salim* \\ Curtin University \\ Mohammad Mahfuz Kabir \\ Bangladesh Institute of International Strategic studies \\ Nasser Al Mawali \\ Sultan Qaboos University
}

\begin{abstract}
This paper examines whether the Gulf Cooperation Council Countries (GCC) exerted any trade enhancing impact on its members by employing standard augmented gravity model as well as stochastic frontier gravity model. Panel data sets are constructed over the period of 1980 to 2008 for imports and exports of the bloc's main trading partners along with GCC countries. The major finding is that the trade enhancing effect of the bloc is significant. However, there is still huge unutilized trade potential between the member countries. Several diagnostic tests were run to check and rectify possible problems of heteroskedasticity and autocorrelation as well as cross-sectional dependence.
\end{abstract}

- JEL Classification: F15

- Keywords: Gravity Model, Trade Effect, Contemporaneous Correlation, Trade Potential, GCC

\footnotetext{
*Corresponding address: Ruhul A Salim; School of Economics \& Finance, Curtin Business School (CBS), Curtin University, P. O. Box U1987, Perth, WA 6845, Australia. E-mail: Ruhul.Salim@cbs.curtin. edu.au./ Mohammad Mahfuz Kabir; Bangladesh Institute of International Strategic studies; Dhaka, Bangladesh Ph:+088-02-8315808, 9336287, 9353808; Ext 114 Fax: +088-02-8312625, e-mail : mahfuzkabir@yahoo.com / Nasser Al Mawali; Department of Economics \& Finance Sultan Qaboos University, P. O. Box No. 20, Al Khod 123 Muscat, OMAN Ph: +968 2414 1848, Fax: + 96824143391 , e-mail: almawali@, squ.edu.com (C2011-Center for Economic Integration, Sejong Institution, Sejong University, All Rights Reserved.
} 


\section{Introduction}

Whether regional trade arrangements (RTAs) facilitate bilateral as well as intraregional trade has long been a research topic of international economics. However, the theoretical explanation and empirical findings are mixed in terms of trade flows and welfare effects of RTA. Some studies (Frankel et al., 1995; Lee and Park, 2007; Bussière et al., 2008) demonstrate mostly positive impact of RTA on bilateral trade flows while some other (Bhagwati and Panagariya, 1996; Bhagwati, 2008) show very little or no impact on bilateral as well inter regional trade flows. The published literature on trade analysis of GCC (Gulf Cooperation Council) countries is very limited. Al-Atrash and Yousef (2000) estimate a gravity equation using data from 18 Gulf countries along with their 43 trade partners reveal that the trade effect of GCC countries is negative for imports, exports and total trade. However, Boughanmi (2008) estimate the import potential of the GCC by examining the intra-Arab imports in an augmented gravity model and reveals that GCC has positive and significant impact on bilateral as well regional trade. Given these contrasting findings the aim of this article is to find the fresh evidence of bilateral trade flows of GCC members by using the augmented gravity model by incorporating major determinants of trade including the effect of GCC for the period of 1980-2008. The contribution of the paper could be summarized in three main points. Firstly, it applies an augmented gravity model of trade in a wide and recent panel data setting to examine the determinants of trade flow of GCC countries. Secondly, it attempts to formally quantify the effect of GCC countries in its trade relationship with its major trading partners. Thirdly, it examines whether the GCC countries are realizing their trade potential amongst themselves by applying stochastic frontier gravity model, which has not been applied so far in examining the scope of enhancing intra-GCC trade.

The rest of the paper proceeds as follows. Section II provides an overview of GCC economies followed by a brief literature review in Section III. Section IV presents the analytical framework as well as a brief description on data. Section V deals with estimation and analysis on empirical findings. Finally, concluding remarks are presented in Section VI. 


\section{Gulf Cooperation Council (GCC): An Overview}

The Cooperation Council for the Arab States of the Gulf (in brief, GCC) was established in 1981 with the objective of coordination and integration in wideranging areas of trade and economic development that include harmonizing regulations across member states, forming a free trade area (FTA) and creating of a customs union by setting common external tariff. The member states of the organization are six: Bahrain, Kuwait, Oman, Qatar, Saudi Arabia and the United Arab Emirates (UAE). In the United Economic Agreement (UEA) of the bloc, signed in 1981, included free trade of items produced within the member states.

The areas of cooperation in this bloc are manifold. The major areas are: political, military, security, legal and judicial, media, economic, human and environmental, supreme council, auditing. In economic arena, the cooperation is wide-ranging:

Table 1. Key Indicators of GCC Countries

\begin{tabular}{lcccccc}
\hline & Bahrain & Kuwait & Oman & Qatar & Saudi Arabia & UAE \\
\hline $\mathbf{1 9 8 1}$ & & & & & & \\
Population (million) & 0.36 & 1.45 & 1.25 & 0.25 & 10.19 & 1.10 \\
GDP (Current US\$ billion) & 3.47 & 25.06 & 7.26 & 7.83 & 183.94 & 32.92 \\
GDP per capita (Constant 2000 US\$) & 10,452 & 15,561 & 5,007 &.. & 15,782 & 44,186 \\
GDP growth (annual \%) & -5.32 & -19.03 & 17.05 & & 4.69 & 2.84 \\
Shares of GDP & & & & & & \\
$\quad$ Agriculture & 1.01 & 0.34 & 2.48 & & 1.01 & 0.84 \\
$\quad$ Manufacturing & 57.80 & 68.69 & 67.13 & & 70.89 & 72.69 \\
$\quad$ Services & 41.18 & 30.96 & 30.40 & & 28.10 & 26.48 \\
Merchandize trade \% of GDP & 244 & 92 & 98 & 83 & 84 & 97 \\
& & & & & & \\
2006 & & & & & & \\
Population (million) & 0.74 & 2.59 & 2.67 & 1.00 & 23.68 & 4.25 \\
GDP (Current US\$ billion) & 15.83 & 101.65 & 35.73 & 52.72 & 356.63 & 163.29 \\
GDP per capita (Constant 2000 US\$) & $14,776^{\mathrm{b}}$ & 23,142 & 10,019 & $29,454^{\mathrm{b}}$ & 9,887 & 25,192 \\
GDP growth (annual \%) & $7.80^{\mathrm{b}}$ & 6.27 & 7.23 & 6.07 & 3.16 & 9.40 \\
Shares of GDP & & & & & & \\
$\quad$ Agriculture & & & $1.97^{\mathrm{c}}$ & & 2.95 & 2.04 \\
$\quad$ Manufacturing & & $51.01^{\mathrm{c}}$ & $53.30^{\mathrm{c}}$ & & 64.63 & 58.85 \\
$\quad$ Services & $144.53^{\mathrm{c}}$ & $44.73^{\mathrm{c}}$ & & 32.43 & 39.11 \\
Merchandize trade \% of GDP & 72 & 91 & 96 & 79 & 150 \\
\hline
\end{tabular}

Note: Data not available. ${ }^{\text {a }}$ data for $1982 .{ }^{\mathrm{b}}$ data for $2005 .{ }^{\mathrm{c}}$ data for 2003.

Source: World Bank. World Development Indicators (online, http://ddp-ext.worldbank.org) and IMFDOTS. 
joint economic action, trade, customs, common market, monetary union, energy, industry, transportation, telecommunication, agriculture, water, and planning and statistics (www.gccsg.org). The GCC Customs Union commenced in January 2003, under which customs duties as well as regulations and procedures that limit intra-bloc trade have been eliminated. Unified external tariff and regulations related to trade and customs procedures have been formulated for non-members (Secretariat General, 2003). Currently the currencies of the member states are pegged against the US dollar. The idea of single currency came right after establishing the bloc on which substantial discussion took place later at the highest policymaking level; formation of a Monetary Union to introduce a common currency is in progress. The following table illustrates some key economic indicators of GCC countries for the year of 1981 when the GCC was first established and twenty five years later.

As of 2006, the total population of GCC member states is 34.93 million with a geographical area of $2,673,000 \mathrm{~km}^{2}$. The total size of the economies is US $\$ 725.85$ billion. All the economies of the bloc are growing at a positive rate, with an average of $5.36 \%$ per annum. Value addition of the manufacturing sector is the highest, ranging from nearly 51 to $65 \%$ of GDP of these countries. The degree if trade integration, measured as merchandize trade as percentage of GDP, range from $72 \%$ (Kuwait) to $150 \%$ (UAE) (Table 1). The countries are gradually diversifying their exports even though it is significantly lower than the other prominent blocs (Figure 1).

The financial markets and monetary policy actions of the GCC economies are found to be significantly linked together in the long run (Darrat and Al-Shamsi, 2005). Real exchange rates in this bloc are closely related and share the same stochastic trend, which implies the readiness of the countries for a currency union

Table 2. Trade Flow of GCC Countries (million US\$)

\begin{tabular}{|c|c|c|c|c|c|c|}
\hline & \multicolumn{3}{|c|}{ IMPORTS FROM } & \multicolumn{3}{|c|}{ EXPORTS TO } \\
\hline & GCC & World & $\%$ of World & GCC & World & $\%$ of World \\
\hline 1981 & $4,629.92$ & $59,570.31$ & 7.77 & $5,603.23$ & $164,741.00$ & 3.40 \\
\hline 1990 & $3,999.828$ & $47,734.75$ & 8.38 & $6,905.782$ & $86,571.02$ & 7.98 \\
\hline 1995 & $5,719.369$ & $66,103.92$ & 8.65 & $6,832.25$ & $100,881.90$ & 6.77 \\
\hline 2000 & $6,746.707$ & $75,326.68$ & 8.96 & $8,029.092$ & $164,388.30$ & 4.88 \\
\hline 2005 & $14,453.01$ & $199,264.80$ & 7.25 & $15,343.8$ & $335,183.20$ & 4.58 \\
\hline 2008 & $27,683.91$ & $385,804.50$ & 7.18 & $28,882.18$ & $630,805.40$ & 4.58 \\
\hline
\end{tabular}

Source: IMF DOTS (online). 
Figure 1. Export Diversification Index for GCC vis-à-vis Other Blocs

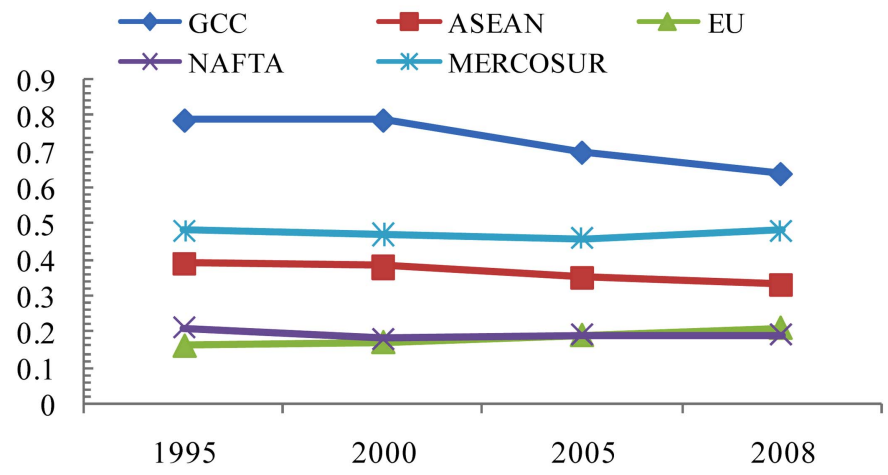

Source: UNCTAD Handbook of Statistics (online).

(Laabas and Limam, 2002). Despite all the commonalities and measures adopted over the years in the areas of economic cooperation, the intra-bloc trade remained meager. Both the magnitude of import and exports of the bloc have increased, but their share in the imports from and exports to the world has remained relatively small (7.18\% in imports and 4.58\% in exports in 2008) (Table 2). ${ }^{1}$ This insignificant trade outcome gives rise to an important analytical question: has the bloc had significant impact on the bilateral trade relations with its important partners? Is there significant scope of trade expansion amongst members of this bloc?

\section{A Review of Literature}

Gravity model is regarded to be the most successful bilateral trade equation, which has been in use for nearly a half century. It is widely used to explore the determinants and effects of bilateral trade of various regional arrangements as well as to assess the differences between potential and actual trade flows. The gravity equation, pioneered by Tinbergen (1962), Pöyhönen (1963), Pullianinen (1963), was initially developed for cross-sectional analysis. Its recent derivation mainly includes complete and incomplete specialization and firm heterogeneity (Deardorff, 1998; Anderson and van Wincoop, 2003; Haveman and Hummels, 2004) that make it an effective tool for trade analysis. Amongst some of the recent empirical studies, Bayoumi and Eichengreen (1998) reveal that both the EC and EFTA

'Trade is rather intense among GCC countries given their industrial base, which implies that the GCC is not just a political bloc (Bolbol, 1999). 
significantly enhanced intra-regional trade particularly in the early years of the blocs. Latin RTAs demonstrated substantial increase in intra-bloc trade in the 1990s in Soloaga and Winters (2001). Egger (2002) also reveals significant unutilized export potential of the OECD countries with other OECD, Central and Eastern European countries.

Eaton and Kortum (2002) find that collective tariff removal increases welfare for most of the OECD countries. The benefits are found to be considerably higher with mobile labour. By examining trade effects of Mercosur-EU (European Union) trade agreement for 20 countries, Martinez-Zarzoso and Nowak-Lehmann (2003) demonstrate that intra-bloc trade effects turn out to be positive and statistically significant, which implies that belonging to either bloc helps trade expansion.

Kirkpatrick and Watanabe (2005) examine the effects of the East African Cooperation Agreement (EACA) for Kenya, Tanzania and Uganda and observe that regional trade cooperation results in a substantially positive effect on the change in trade among the three countries. Assessing ex post effects of regional trade agreements including 130 countries with a panel gravity model for the period of 1962-1996, Carrère (2006) reveals that regional agreements result in a substantial increase in trade among members, while they decrease trade with rest of the world. Lee and Shin (2006) examines the impact of East Asia's trade integration in a panel gravity model for the period $1948-1999$ covering 175 countries. They reveal that the integration has had a substantial trade creation and no diversion effect.

Baier and Bergstrand (2007) observe that the effect of FTAs on trade flows is substantial, and in general an FTA nearly doubles bilateral trade of two members after 10 years. Conversely, Lee and Park (2007) find that the RTA membership increases intra-member trade that ranges from 119 to $299 \%$. In investigating trade effects of Economic Integration Agreements (EIAs) in the Americas, Baier et al. (2007) reveal that trade effects of membership in the EIAs during the period 19602000 happen to be significantly larger than that suggested by the previous ex ante projections in partial and general equilibrium models as well as empirical estimates in the cross-country gravity models.

Kandogan (2008) applies a panel gravity equation to estimate the trade effect of regional groups and demonstrates that the effect is positive for economic cooperation agreements and PTAs, but that there is an insignificant incremental effect in the case of FTAs. Interestingly, he finds that customs unions have a positive effect, while it is mixed for monetary unions and negative for economic area and full integration schemes. Helpman et al. (2008) reveal that the influence of FTA is 
positive and significant in bilateral trade flow of 158 countries for 1985 in reduced and full sample, both for benchmark model and Heckman selection model. Bussière et al. (2008) find positive and significant trade effect of ASEAN, Mercosur, Central European Free Trade Agreement (CEFTA) and NAFTA, and ambiguous impact of EU in various panel data estimators over a period of 1980-2003.

Westerlund and Wilhelmsson (2011) examine the trade effect of the $1995 \mathrm{EU}$ enlargement using the fixed effects panel Poisson Maximum Likelihood estimator and data over the period 1992-2002 for EU and other developed countries. They find that the EU brought on substantial trade diversion but no trade creation, and the trade diversion effect is significantly larger than the trade creation effect. Cipollina and Salvatici (2010) conducted a meta-analysis of estimates obtained from fixed and random effects models of the RTAs' effect size on bilateral trade. The study reveals that RTAs have significant effects on trade flows.

The published literature on trade analysis of GCC is scarce. Only a few recent articles examine the trading pattern and potential of the bloc's bilateral trade with its major trading partners. Al-Atrash and Yousef (2000) estimate a gravity equation using Tobit model to examine the magnitude of trade of Arab countries over the period 1995-97 for 18 Arab countries and 43 other countries. They reveal that the trade effect of GCC countries is negative and significant for imports; exports and total trade. The observed intra-Arab trade and Arab trade with the world were lower than predicted, which suggests greater scope for regional integration and multilateral integration. However, the study is confined to one period (average of 1995-1997), which cannot represent the trading pattern over time.

Nugent (2002) examines the potential of intra-regional and extra-regional trade of Middle East and North African (MENA) countries. It, however, reveals strong evidence that sub-regional trade arrangements, such as the Arab Mashreq countries and the Arab Maghreb Union failed to increase trade, while it is weak for GCC countries. Mehanna (2003) estimates the trade effects of GCC in the context of politics and culture on Middle East trade. It reveals that GCC had positive and significant imports effect when religion (Islam), political freedom and corruption were considered. Bolbol and Fatheldin (2005) analyze the determinants of intraArab exports. They find that intra-Arab exports are below the potential and that this deficiency mainly arises from the lack of sufficient exports between the GCCMaghreb and Maghreb-Mashreq countries.

Boughanmi (2008) estimates the import potential of the GCC by examining the intra-Arab imports in an augmented gravity model. They reveal that GDP of both 
the importers and exporters are positive and distance effect is negative in pooled cross-section (PCS) and FEE. Common border between them influence positively on trade flows in the PCS analysis. The GCC dummy has been found to be positive and significant in both pooled time series-cross-sectional regression and fixed effects model. Boughanmi et al. (2009) further assess the intra-GCC trade performance and estimate the trade potential by using disaggregated data for total exports, total agricultural food exports and seven agricultural food commodities according to the Standard International Trade Classification (SITC) for the period 1994-2004. The results reveal that the GCC trading arrangement promoted intrabloc trade integration in agricultural food products compared to aggregate trade.

Thus, it is important to examine whether formation of GCC has really exerted influence on its trade and whether there is significant scope of trade expansion. Such an exercise would help understand the importance and directions of factors that are commonly believed to exert influence of trade flows of trading blocs across the world. It would also indicate the relative importance of this bloc in bilateral trade flows of the countries involved. Moreover, estimation of trade potential would help policymakers remove the existing behind and beyond the border constraints, thereby further facilitating trade enhancement in this bloc.

\section{Methodology and Data}

\section{A. Examining trade effects of GCC}

In the Tinbergenian or 'basic' gravity model GDP of the traders and distance between them are the determinants of bilateral trade. Previous studies find positive and significant coefficient of GDP (e.g., Athukorala, 2009; Bussière and Schnatz, 2009; Kandogan, 2008). Distance elasticity has been found to be negative (Disdier and Head, 2008; Bussière et al., 2008; Helpman et al., 2008).

Augmented gravity models incorporate real exchange rate, common border, common language and RTA dummies to capture other relevant factors affecting bilateral trade. Common border between two countries leads to increased trade, and it is found to be positive and significant in various estimates (e.g., Wolf, 2000; Eaton and Kortum, 2002; Gil-Pareja et al., 2005). Kandogan (2008) reveals positive and significant trade effect of common border and common language of various economic blocs. The effect of common language turns out to be trade enhancing (Hutchinson, 2002; Eaton and Kortum, 2002; Bussière and Schnatz, 2009). 
Anderson and van Wincoop (2003) find negative impact of border barriers on bilateral trade flows. The real depreciation has been found to be significantly export enhancing (Athukorala, 2009) and import reducing (Carrère, 2006). The impact of trade agreements is mostly positive on bilateral trade flows (Frankel et al., 1995; Lee and Park, 2007; Bussière et al., 2008).

The gravity equation of bilateral trade of GCC countries can be written as:

$$
\begin{aligned}
\ln T_{i j t}= & \beta_{0}+\beta_{1} \ln Y_{i t}+\beta_{2} \ln Y_{j t}+\beta_{3} \ln D i s t_{i j}+\beta_{4} \ln R E R_{i j t} \\
& +\beta_{5} A_{d j}+\beta_{6} \text { Lang }_{i j}+\beta_{7} G C C_{i j t}+\varepsilon_{i j t}
\end{aligned}
$$

where $T_{i j t}$ is the value of trade flows (imports or exports) between home country $i$ and destination country $j$ in time period $t ; Y_{i}$ and $Y_{j}$ denote gross domestic product of $i$ and $j$, respectively in time $t$; and $D i s t_{i j}$ refers to bilateral geographical distance between two countries. $A d j_{i j}$, Lang $_{i j}$, and $G C C_{i j}$ are binary variables for common land border, language and membership in GCC, respectively, and $\varepsilon_{i j t}$ is the error term. The GDP of local and destination countries are trade enforcement variables. The higher the national income of traders the more the trade flows, and thus $\beta_{1,} \beta_{2}>0$. The distance is a trade resisting factor and thus $\beta_{3}<0$ since greater distance increases transport cost and thus increase the price of traded items. ${ }^{2}$ The three binary variables are trade enhancing factors. In implies natural log, which is prefixed except for binary variables to help avoid the problem of heteroskedasticity. $R E R_{i j t}$ implies real exchange rate between them in $t$, which is constructed by

$$
R E R_{i j t}=E R_{i j t}\left(P_{j t} / P_{i t}\right)
$$

where $P_{i t}$ and $P_{j t}$ are price levels of home and partner countries respectively. $E R_{i j t}$ is the bilateral nominal exchange rate between the currencies of foreign country $j$ and the home country $i .^{3}$ Carrère (2006) and Serlenga and Shin (2007) argue that an increase in the bilateral real exchange rate reflects depreciation of the importer's currency against that of the exporters. Thus, the coefficient of $R E R$ is expected to be negative in the imports panel. The impact of the formation of GCC on intra-bloc

\footnotetext{
${ }^{2}$ According to Krugman (1991) and Papazoglou et al. (2006), close geographical distance and regional proximity help increase trade flows be reducing transport costs and thus favorable for economic cooperation in attaining mutual gains.

${ }^{3}$ The formula of calculating bilateral exchange rate is $E R_{i j t}=L C_{i t} / L C_{j t}$, where LC is the local currency units per US dollar.
} 
trade can be examined after obtaining $\hat{\beta}_{7}$ by estimating the gravity equation (1). Following Halvorsen and Palmquist (1980), it can be calculated by $\left(e^{\hat{\beta}_{\gamma}}-1\right) * 100$ since the dependent variable is in the log form.

\section{B. Examining intra-GCC trade potential}

The usual assumption in the standard gravity model is that the trading environment in the home country does not impose any restrictions on its imports and exports. Despite admitting that the home country possesses behind the border constraints and it faces beyond the border constraints from the partners, these constraints are assumed to be insignificant and are randomly distributed across observations in standard models. However, such an assumption would be strong and may not reflect the real world circumstances.

According to Drysdale and Garnaut (1982), Baldwin and Taglioni (2006), and Kalirajan and Singh (2008), trade flows can be affected by three factors. First, natural constraints, such as geographical distance or transport cost. Second, behind the border constraints, which stem from socio-economic, institutional and political factors, and infrastructure rigidities prevailing in exporting countries. Third, beyond the border constraints, which include institutional and infrastructure rigidities in importing countries. These can be removed through various trade facilitating measures.

In the stochastic frontier analysis of bilateral trade flows, higher variation in trade performance explained by behind and beyond the border constraints indicates greater distance from the trade frontier, given the core determinants of trade. Trade potential can be measured in the context of achieving it at a 'frontier', which estimates a level of trade that might be attained in the case of the most open and frictionless trade possible given current trade, transport, and institutional efficiencies or practices (Armstrong et al., 2008). To understand the nature of the stochastic frontier problem of bilateral trade, suppose that the trade function is $f\left(x_{i j t}\right.$, $\beta$ ), where $x_{i j t}$ is the vector of economic, geographic, social and institutional factors that influence traders $i$ and $j$ at time $t$, and $\beta$ is the vector of unknown parameters. Assuming that trade is subject to random shocks, the stochastic frontier gravity model in a general form can be written as

$$
y_{i j, t}=f\left[\left(x_{i j t}, \beta\right) \cdot \tau_{i j t} \cdot \exp \left(v_{i j t}\right)\right]
$$

where the stochastic error term, $v_{i j t}$, represents the random exogenous shocks to the 
trading processes. Although trade is subject to different kind of shocks, the term is assumed to follow a common distributional pattern. Thus, $v_{i j t}$ is a two-sided normally distributed variable. Assuming $\tau_{i j t}$ to be an exponential as $\exp \left(-u_{i j t}\right)$, where $u_{i j t}$ is a stochastic variable that follows a non-negative distribution, Equation (3) can be written in the following log-linear Cobb-Douglas form

$$
\ln y_{i j t}=\beta_{0}+\sum_{k=1}^{m} \beta_{k} \ln x_{i j t}+v_{i j t}-u_{i j t}
$$

where the trade efficiency term $u_{i j, t}$ is time-varying. Equation (4) provides estimates for two different specifications of the non-negative error $u_{i j, t}$ : time invariant (TI) and time varying. In the simplest specification, $u_{i j, t}$ is a time-invariant truncated normal random variable, and $u_{i j, t}$ and $v_{i j, t}$ are distributed independently. The stochastic frontier gravity model provide estimates of the trade potential that can be obtained if the bilateral trade operates at the frontier or maximum level when the trade resistances are at minimum or absent (Kabir, 2010 and Kabir and Salim, 2010). Thus, the bilateral trade potential can be envisioned as the maximum possible trade which can take place if there is no resistance between them given the determinants (Kalirajan, 1999). As most of the trade resistances cannot be quantified and thus remain unobserved, these together constitute the non-negative disturbance term. Thus, the stochastic frontier gravity model can be written as

$$
\begin{aligned}
\ln T_{i j t} & =\beta_{0}+\beta_{1} \ln Y_{i t}+\beta_{2} \ln Y_{j t}+\beta_{3} \ln D_{i s t_{i j}}+\beta_{4} \ln R E R_{i j t}+\beta_{5} A d j_{i j} \\
& +\beta_{6} \operatorname{Lang}_{i j}+\beta_{7} G C C_{i j t}+v_{i j t}-u
\end{aligned}
$$

\section{Data sources}

Two panel data sets are constructed, for imports and exports, over data period of 29 years, from 1980 to 2008 . The sample countries are drawn from 20 important trading partners of the GCC countries including the bloc members. ${ }^{4}$ The annual data on aggregate imports and exports are gathered from the IMF Direction of Trade Statistics (DOTS). Data on GDP are collected from the WDI. The data on distance, common border and common official language come from the Centre d'Etudes Prospectives et d'Informations Internationales (CEPII).

\footnotetext{
${ }^{4}$ The countries involved in the panels are: Australia, Bahrain, Bangladesh, Belgium, Brazil, Hong Kong, China, France, Germany, India, Indonesia, Iran, Italy, Japan, Jordan, Kenya, Korea, Kuwait, Lebanon, Malaysia, Netherlands, New Zealand, Oman, Pakistan, Philippines, Qatar, Saudi Arabia, Singapore, South Africa, Spain, Sri Lanka, Sweden, Switzerland, Syria, Tanzania, Thailand, Turkey, United Arab Emirates, United Kingdom, United States and Yemen.
} 
Bilateral exchange rate data are not available in the standard secondary sources. Therefore, it is calculated from official exchange rates of individual countries, which are collected from the WDI. Brun et al. (2005) primarily use consumer price index (CPI) to represent the price level, and GDP deflator is used in case if CPI data was not available. We use the GDP deflator as the price indicator, which is an overall measure of price level of domestically produced items. In an increasingly interdependent world, trade does not take place only on some specific bundles of consumer items on which the CPI is constructed. Rather, many capital and intermediate products are traded as well, the prices of which are embedded in GDP deflator. These are collected from the World Bank World Tables. Data on the presence of a common border are taken from CEPII. A very small of observations has zero values in the panels of both imports and exports. To address this problem, the standard procedure is followed by adding one with zero and then log-transform to get zero values again in the panel.

\section{Estimation and Analysis of Results}

\section{A. Trade effects of GCC}

Fixed Effect Model (FEM) versus Random effect Model (REM): A panel gravity model can be estimated by the Fixed Effects Model (FEM). However, it fails to recognize the impact of time invariant regressors, such as distance, common language, common border, etc. (Egger, 2002). Random Effects Model (REM) can accommodate time invariant independent variables $\left(x_{i j t}\right)$. Egger (2002) applies Hausman's $\chi^{2}$ statistic to test the REM versus the FEM in gravity equation and finds the FEM to be consistent but the REM is not. Moreover, Baier and Bergstrand (2007) argue that the FEM is appropriate in estimating gravity equations due to the fact that the latent variables $\left(u_{i j}\right)$ influence the regressors, such as bilateral trade agreements (BTA) and the volume of trade.

Equation (1) has been estimated by FEM and REM, in which a significant Hausman $\chi^{2}$ statistics of FEM versus REM suggest that traditional FEM provides consistent estimates. This is supported by a high negative correlation between unobserved country specific effects $u_{i}$ and $X b$ (reported in the bottom of Table 3). In both $Y_{i t}$ and $Y_{j t}$ influence positively and significantly on the group's import flows. The distance elasticity is negative and significant at $1 \%$ level in REM; FEM automatically drops time invariant determinants, such as Dist, Adj and Lang. The 
Table 3. Fixed and Random Effects Estimates

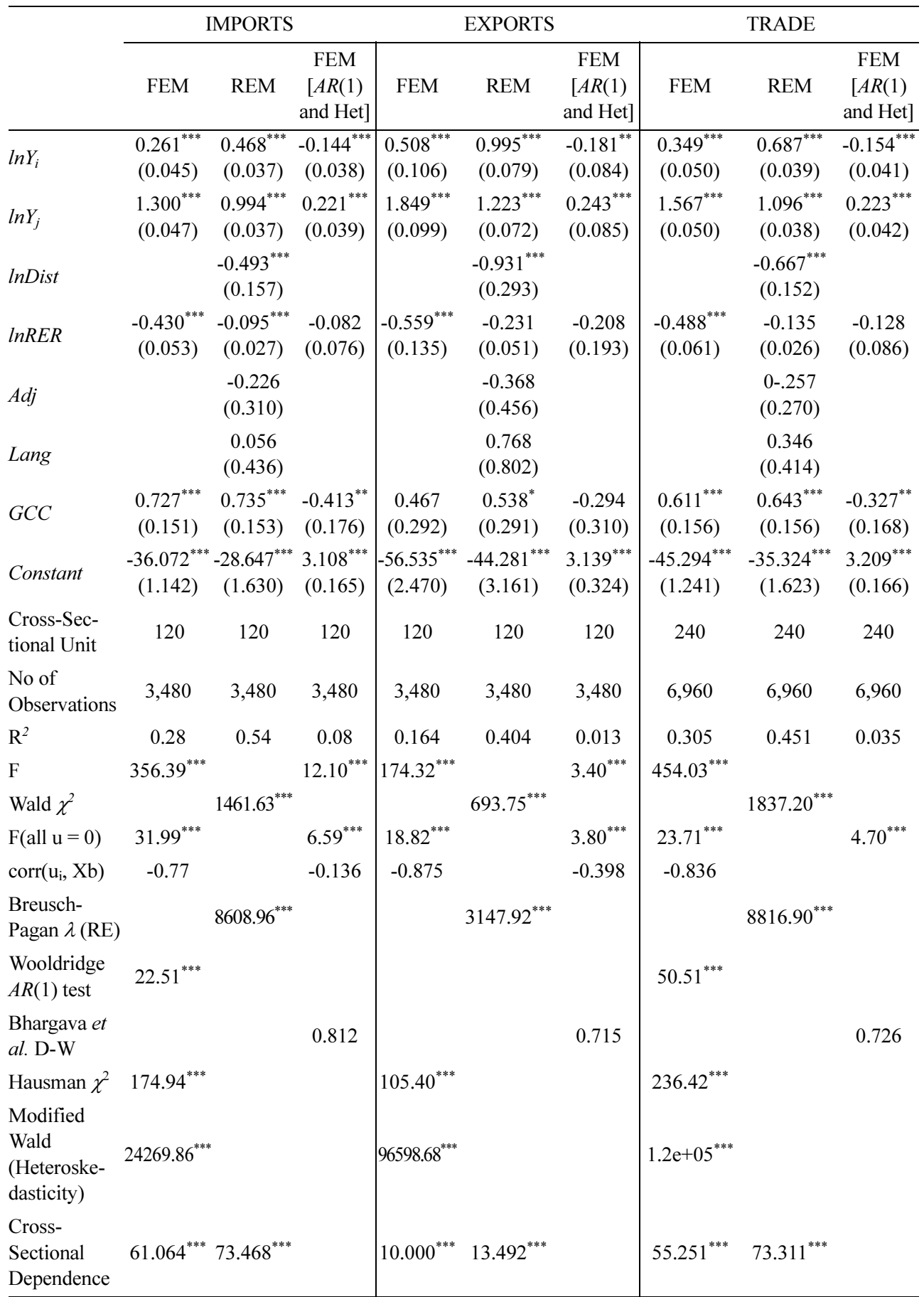

Note: Numbers in the parentheses are standard errors. $* * *, * *$ and $*$ indicate that estimated coefficients are significant at 1,5 and $10 \%$ levels respectively. 
$R E R$ elasticity has been found to be negative and significant in imports panel for both the estimates. It indicates that a real depreciation discourages imports of this bloc. Most importantly, the coefficient of GCC is strongly significant. It implies that belonging to GCC has an encouraging influence on imports of the group members. The import enhancement effect of this bloc is estimated to be $106.89 \%$ in traditional FEM.

Heteroskedasticity and AR(1): Unless otherwise stated, the FEM follows $\varepsilon_{i j t} \sim$ $\operatorname{iid}\left(0, \sigma^{2}\right)$, which implies homoskedasticity, no autocorrelation and no contemporaneous correlation within the panel. In practice, panels often witness these problems, which necessitate making explicit assumptions about the presence of unequal error variance and the structure of error correlation. If heteroskedasticity and autocorrela -tion are present in the panel but not addressed, the estimates will be inefficient. However, robust standard errors provide the standard errors in FEM that are robust to heteroskedasticity and non-normality, but not to autocorrelation (Kézdi, 2004). Stock and Watson (2006) also notice that the conventional Eicker-Huber-White heteroskedasticity-robust variance matrix estimator applied to the FEE for panel data even with no autocorrelation turns out to be inconsistent if $T(>2)$ is fixed and $N$ increases.

Our imports panel suffers from both the problems, which is evident from significant modified Wald and Wooldridge $A R(1)$ tests, respectively. This indicates that controlling for these problems provides consistent as well as efficient estimates for the gravity model. To address the problem of serial correlation in the panel, Egger (2002) controlled for $A R(1)$ in the Hausman-Taylor framework to obtain efficient estimates. We therefore estimate the gravity model after Baltagi and $\mathrm{Wu}$ (1999) transformations, which allow for panel heteroskedasticity and $A R(1)$. The results are reported in the right-hand columns of Table 3, which suggest that both the estimators provide few significant coefficients. Since the correlation between $u_{i}$ and $X b$ is very low (only -0.14 ), REM provides reliable estimate of the gravity model. In this estimate, GDP elasticity of both local and destination countries is positive and significant, and import enhancement effect of GCC is estimated to be 76.47 REM allowed for heteroskedasticity and serial correlation.

Dealing with zero trade and heteroskedasticity: The bilateral trade data commonly suffers from zero trade values, which is traditionally tackled by qualitative dependent variable models. Santos Silva and Tenreyro $(2006,2007)$ suggest that the gravity equation should be estimated by pseudo-maximum-likelihood (PML) estimation technique as it provides a natural way to deal with zero values of the dependent 
variable. PML also gives consistent estimates in the presence of heteroskedasticity (Santos Silva and Tenreyro, 2006, p. 641). Under different heteroskedasticity assumptions, they reveal that fixed effects Poisson PML (FE-PPML) and Gamma PPML (GPPML) provide lower bias in the estimated coefficients than tobit, nonlinear least squares, and standard OLS estimates (Santos Silva and Tenreyro, 2006, p. 648). As we can see in Table 4, FE-PPML provides positive and significant import and trade effect of GCC, while GPPML estimate of GCC coefficient turns out to be greater and significant at $1 \%$ level.

Cross-Sectional Dependence (CSD): When the residual terms do not follow the iid assumption, traditional FEM and REM are no longer valid (Driscoll and Kraay,

Table 4. Pseudo-maximum-likelihood (PML) Estimates

\begin{tabular}{|c|c|c|c|c|c|c|}
\hline & \multicolumn{2}{|c|}{ IMPORTS } & \multicolumn{2}{|c|}{ EXPORTS } & \multicolumn{2}{|c|}{ TRADE } \\
\hline & $\begin{array}{c}\text { Poisson } \\
\text { Pseudo-ML, } \\
\text { Fixed Effects }\end{array}$ & $\begin{array}{c}\text { Gamma } \\
\text { Poisson } \\
\text { Pseudo-ML }\end{array}$ & $\begin{array}{c}\text { Poisson } \\
\text { Pseudo-ML, } \\
\text { Fixed Effects }\end{array}$ & $\begin{array}{c}\text { Gamma } \\
\text { Poisson } \\
\text { Pseudo-ML }\end{array}$ & $\begin{array}{c}\text { Poisson } \\
\text { Pseudo-ML, } \\
\text { Fixed Effects }\end{array}$ & $\begin{array}{c}\text { Gamma } \\
\text { Poisson } \\
\text { Pseudo-ML }\end{array}$ \\
\hline $\ln Y_{i}$ & $\begin{array}{c}-0.073^{* * *} \\
(0.001)\end{array}$ & $\begin{array}{l}0.928^{* * *} \\
(0.001)\end{array}$ & $\begin{array}{l}0.111^{* * *} \\
(0.001)\end{array}$ & $\begin{array}{l}1.118^{* * *} \\
(0.002)\end{array}$ & $\begin{array}{l}0.026^{* * *} \\
(0.001)\end{array}$ & $\begin{array}{l}1.027^{* * *} \\
(0.001)\end{array}$ \\
\hline $\ln Y_{j}$ & $\begin{array}{l}1.700^{* * *} \\
(0.003)\end{array}$ & $\begin{array}{c}5.470^{* * *} \\
(0.016)\end{array}$ & $\begin{array}{l}1.807^{* * *} \\
(0.002)\end{array}$ & $\begin{array}{c}6.092^{* * *} \\
(0.016)\end{array}$ & $\begin{array}{l}1.769^{* * *} \\
(0.002)\end{array}$ & $\begin{array}{c}5.867^{* * *} \\
(0.011)\end{array}$ \\
\hline $\ln D i s t$ & & $\begin{array}{l}0.191^{* *} \\
(0.129)\end{array}$ & & $\begin{array}{l}0.067^{* * *} \\
(0.070)\end{array}$ & & $\begin{array}{l}0.084^{* * *} \\
(0.048)\end{array}$ \\
\hline $\ln R E R$ & $\begin{array}{c}-0.929^{* * *} \\
(0.002)\end{array}$ & $\begin{array}{l}0.395^{\text {*** }} \\
(0.001)\end{array}$ & $\begin{array}{c}-1.322^{* * *} \\
(0.002)\end{array}$ & $\begin{array}{c}0.266 \\
(0.000)\end{array}$ & $\begin{array}{c}-1.167^{* * *} \\
(0.001)\end{array}$ & $\begin{array}{l}0.311^{* * *} \\
(0.000)\end{array}$ \\
\hline Adj & & $\begin{array}{c}0.494 \\
(0.471)\end{array}$ & & $\begin{array}{c}0.683 \\
(0.777)\end{array}$ & & $\begin{array}{c}0.652 \\
(0.482)\end{array}$ \\
\hline Lang & & $\begin{array}{c}1.312 \\
(2.298)\end{array}$ & & $\begin{array}{c}1.341 \\
(3.748)\end{array}$ & & $\begin{array}{c}0.732 \\
(1.112)\end{array}$ \\
\hline$G C C$ & $\begin{array}{l}0.300^{* * *} \\
(0.017)\end{array}$ & $\begin{array}{c}1.350 \\
(0.024)\end{array}$ & $\begin{array}{c}0.019 \\
(0.013)\end{array}$ & $\begin{array}{c}1.019 \\
(0.013)\end{array}$ & $\begin{array}{l}0.120^{* * *} \\
(0.010)\end{array}$ & $\begin{array}{l}1.128^{* * *} \\
(0.012)\end{array}$ \\
\hline $\ln \alpha$ & & $\begin{array}{l}1.600^{* * *} \\
(0.099)\end{array}$ & & $\begin{array}{l}1.902^{* * *} \\
(0.119)\end{array}$ & & $\begin{array}{l}1.798^{* * *} \\
(0.076)\end{array}$ \\
\hline$\alpha$ & & $\begin{array}{l}4.957^{* * *} \\
(0.491)\end{array}$ & & $\begin{array}{l}6.703^{* * *} \\
(0.803)\end{array}$ & & $\begin{array}{l}6.040^{* * *} \\
(0.459)\end{array}$ \\
\hline Time Perio & : 1980-2008 & & & & & \\
\hline Wald $\chi^{2}$ & $365624.36^{* * *}$ & $365309.50^{* * *}$ & $711892.55^{* * *}$ & $711703.87^{* * *}$ & $1.06 \mathrm{e}+06^{* * *}$ & $1.06 \mathrm{e}+06^{* * *}$ \\
\hline $\begin{array}{l}\text { Log } \\
\text { Likelihood }\end{array}$ & -176949.73 & -178282.08 & -244625.99 & -245534.26 & -428865.43 & -431119.25 \\
\hline
\end{tabular}

Note: Numbers in the parentheses are standard errors. ${ }^{* * *},{ }^{* *}$ and ${ }^{*}$ indicate that estimated coefficients are significant at 1,5 and $10 \%$ levels respectively. 
1998). The problem of CSD arises mainly due to (i) the presence of common shocks and unobserved components that eventually become part of the error term; (ii) spatial dependence; and (iii) idiosyncratic pair-wise dependence in the error term without any specific pattern of common components or special dependence (Pesaran, 2004). Assuming that CSD stems from common factors that are unobserved but uncorrelated with the explanatory variables, the estimators that assume iid of disturbances turn out to be consistent but inefficient and produce biased standard errors. Conversely, if the unobserved components that create interdependencies across the cross-section are correlated with the explanatory variables, the FEM will be biased as well as inconsistent.

Spatial dependence is a common feature in panel data due to interactions among economic agents. Therefore, robust inference in the presence of heteroskedasticity and spatial dependence is an important problem in spatial data analysis (Kim and Sun, 2011). Geography plays a major influence in many economic areas. Trade declines with geographic distance, and per-capita incomes vary with climatic conditions (Anderson and van Wincoop, 2004). Keller and Shiue (2007) studied interregional trade by examining the spatial pattern of rice price differences in 121 Chinese prefectural markets and found that spatial features have shaped the expansion of interregional trade. They suggested that using spatial methods gives a much clearer picture of the evolution of interregional trade (Keller and Shiue, 2007, p.132). Kelejian and Prucha (2007) revealed that spatial interactions could be due to competition between cross sectional units, externalities, regional issues, etc. Specifying the spatial dependence between observations in a panel data model may incorporate a spatial autoregressive process in the error term, or the model may contain a spatially autoregressive dependent variable (Elhorst, 2003). Kapetanios et al. (2011) reveal that spatial techniques are often adapted using alternative measures of "economic distance" in economic applications. In the case of panel data models where $N$ is small (typically $N<10$ ) and $T$ is large, the standard approach is to treat the equations from the different cross-section units as a system of seemingly unrelated regression equations (SURE) and then estimate the system by generalized least squares (GLS) techniques. However, SURE approach is not applicable if the errors are correlated with the regressors and/or if the panels have a large cross-sectional dimension, which is our present case.

In the presence of CSD, residuals can be either heteroskedastic across panels or heteroskedastic and contemporaneously correlated across panels. Here, two other assumptions may also be made for the estimator: i.e., common $A R(1)$ for all the 
Table 5. Prais-Winsten Estimates

\begin{tabular}{|c|c|c|c|c|c|c|}
\hline & \multicolumn{2}{|c|}{ IMPORTS } & \multicolumn{2}{|c|}{ EXPORTS } & \multicolumn{2}{|c|}{ TRADE } \\
\hline & $\begin{array}{c}\text { Common } \\
A R(1) \\
\text { with Het }\end{array}$ & $\begin{array}{c}\text { Panel- } \\
\text { Specific } \\
A R(1) \\
\text { with Het }\end{array}$ & $\begin{array}{c}\text { Common } \\
A R(1) \\
\text { with Het }\end{array}$ & $\begin{array}{c}\text { Panel- } \\
\text { Specific } \\
A R(1) \mathrm{w} \\
\text { ith Het }\end{array}$ & $\begin{array}{c}\text { Common } \\
A R(1) \\
\text { with Het }\end{array}$ & $\begin{array}{c}\text { Panel- } \\
\text { Specific } \\
A R(1) \\
\text { with Het }\end{array}$ \\
\hline $\ln Y_{i}$ & $\begin{array}{c}0.380^{* * *} \\
(0.034)\end{array}$ & $\begin{array}{c}0.383^{* * *} \\
(0.036)\end{array}$ & $\begin{array}{l}0.771^{* * *} \\
(0.065)\end{array}$ & $\begin{array}{c}0.835^{* * *} \\
(0.062)\end{array}$ & $\begin{array}{l}0.501^{* * *} \\
(0.034)\end{array}$ & $\begin{array}{l}0.586^{* * *} \\
(0.036)\end{array}$ \\
\hline $\ln Y_{j}$ & $\begin{array}{l}0.600^{* * *} \\
(0.036)\end{array}$ & $\begin{array}{l}0.615^{* * *} \\
(0.037)\end{array}$ & $\begin{array}{l}0.607^{* * *} \\
(0.057)\end{array}$ & $\begin{array}{l}0.628^{* * *} \\
(0.063)\end{array}$ & $\begin{array}{l}0.593^{* * *} \\
(0.034)\end{array}$ & $\begin{array}{l}0.591^{* * *} \\
(0.038)\end{array}$ \\
\hline $\ln$ Dist & $\begin{array}{c}-0.202^{* *} \\
(0.089)\end{array}$ & $\begin{array}{c}-0.187^{* *} \\
(0.074)\end{array}$ & $\begin{array}{c}-0.394^{* *} \\
(0.176)\end{array}$ & $\begin{array}{c}-0.459^{* * *} \\
(0.179)\end{array}$ & $\begin{array}{c}-0.247^{* * *} \\
(0.093)\end{array}$ & $\begin{array}{c}-0.291^{* * *} \\
(0.094)\end{array}$ \\
\hline $\ln R E R$ & $\begin{array}{l}0.049^{* *} \\
(0.020)\end{array}$ & $\begin{array}{c}0.031^{*} \\
(0.019)\end{array}$ & $\begin{array}{c}-0.102^{* * *} \\
(0.039)\end{array}$ & $\begin{array}{c}-0.186^{* * *} \\
(0.033)\end{array}$ & $\begin{array}{l}-0.004 \\
(0.022)\end{array}$ & $\begin{array}{c}-0.059^{* * *} \\
(0.022)\end{array}$ \\
\hline Adj & $\begin{array}{c}0.079 \\
(0.269)\end{array}$ & $\begin{array}{c}-1.145^{* * *} \\
(0.405)\end{array}$ & $\begin{array}{c}0.222 \\
(0.270)\end{array}$ & $\begin{array}{c}0.156 \\
(0.341)\end{array}$ & $\begin{array}{c}0.232 \\
(0.200)\end{array}$ & $\begin{array}{l}-0.261 \\
(0.282)\end{array}$ \\
\hline Lang & $\begin{array}{c}-0.661^{* *} \\
(0.325)\end{array}$ & $\begin{array}{l}-0.188 \\
(0.301)\end{array}$ & $\begin{array}{l}-0.402 \\
(0.469)\end{array}$ & $\begin{array}{l}-0.174 \\
(0.475)\end{array}$ & $\begin{array}{l}-0.544^{* *} \\
(0.273)\end{array}$ & $\begin{array}{l}-0.468^{*} \\
(0.275)\end{array}$ \\
\hline$G C C$ & $\begin{array}{c}0.473^{* * *} \\
(0.173)\end{array}$ & $\begin{array}{l}0.450^{* * *} \\
(0.162)\end{array}$ & $\begin{array}{l}0.507^{* * *} \\
(0.195)\end{array}$ & $\begin{array}{l}0.515^{* * *} \\
(0.185)\end{array}$ & $\begin{array}{l}0.471^{* * *} \\
(0.128)\end{array}$ & $\begin{array}{l}0.495^{* * *} \\
(0.123)\end{array}$ \\
\hline Constant & $\begin{array}{c}-17.959^{* * *} \\
(1.451)\end{array}$ & $\begin{array}{c}-18.993^{* * *} \\
(1.316)\end{array}$ & $\begin{array}{c}-26.367^{* * *} \\
(2.484)\end{array}$ & $\begin{array}{c}-28.254^{* * *} \\
(2.542)\end{array}$ & $\begin{array}{c}-20.432^{* * *} \\
(1.383)\end{array}$ & $\begin{array}{c}-22.325^{* * *} \\
(1.413)\end{array}$ \\
\hline Cross-Sectional Unit & 120 & 120 & 120 & 120 & 240 & 240 \\
\hline $\begin{array}{l}\text { No of Observations } \\
\text { Time Period: } 1980-2008\end{array}$ & 3480 & 3480 & 3480 & 3480 & 6960 & 6960 \\
\hline $\mathrm{R}^{2}$ & 0.370 & 0.830 & 0.184 & 0.540 & 0.237 & 0.684 \\
\hline Wald $\chi^{2}$ & $724.93^{* * *}$ & $814.00^{* * *}$ & $362.09^{* * *}$ & $368.16^{* * *}$ & $822.32^{* * *}$ & $817.25^{* * *}$ \\
\hline Time Effect & $862.29^{* * *}$ & $489.28^{* * *}$ & 181.71 & 460.71 & $1044^{* * *}$ & $949.99^{* * *}$ \\
\hline
\end{tabular}

Note: Numbers in the parentheses are standard errors. ${ }^{* * *},{ }^{* *}$ and ${ }^{*}$ indicate that estimated coefficients are significant at 1,5 and $10 \%$ levels respectively.

panels and panel-specific $A R(1)$, where the correlation parameter is unique for each panel. Panel-specific $A R(1)$ assumes that the degree of correlation varies across country pairs and corrects for contemporaneous error correlation across the crosssection units (Papazoglou et al., 2006).

Breusch and Pagan (1980) LM test that is used to examine CSD if $T>\mathrm{N} .{ }^{5}$ The present study involves $T<\mathrm{N}$, for which the suitable test is proposed by Pesaran (2004). The estimated CSD statistic implies that whether FEM or REM is applied, the panel suffers from CSD, i.e., the disturbances are no longer iid. To address this

${ }^{5}$ The test is valid for fixed $N$ as $\mathrm{T} \rightarrow \infty$. 
problem, two cases of robust Prais-Winsten regression estimates of the gravity equation have been reported in Table 4. These are: (i) heteroskedasticity with common $A R$ (1) and (ii) heteroskedasticity with panel-specific $A R$ (1). The results remain almost the same in our estimates terms of sign and significance of estimated coefficients of the two cases. GDP of both local and destination countries have been found to have positive and positive influence on trade of GCC countries, which is in line with the expectation. Distance elasticity is negative and significant at $1 \%$ level, which concurs with the theory. Surprisingly, the RER elasticity appears to be positive, which implies that a $100 \%$ real depreciation increases $4.9 \%$ of imports of GCC countries in the estimate where common $A R(1)$ with heteroskedasticity is assumes, while it is estimated to be $3.1 \%$ for panel-specific $A R(1)$. This result contradicts with the theory and needs further investigations.

The coefficients of $A d j$ and Lang have been found to be negative and significant at $1 \%$ level in panel-specific $A R(1)$ and common $A R(1)$ cases, respectively. This result is contradictory with the theory, but is supported by two recent studies. Kirkpatrick and Watanabe (2005) find the effect of common border negative in the context of Sub-Saharan Africa; but it was small and insignificant in their estimation. Nevertheless, our result supports Feenstra et al. (2001), who also find negative and significant common border effect on exports of differentiated goods of the OECD.

Feenstra (2002) derives a negative coefficient of border effect (-1.55) in examining the US-Canada trade, which is consistent with that of Anderson and van Wincoop (2003) (-1.65). According to the best of our knowledge, the theoretical gravity equations do not derive the effects of common language on trade flows. Melitz (2008) describes the channels through which common language reduces the price of bilateral trade by decreasing translation cost, which is not also based on the theory. We, however, find that the FEM approach to the gravity equation for GCC drops the time-invariant variables, both Adj and Lang, supporting Egger (2002) and Baltagi et al. (2003) amongst others. Thus, the effects of common border impacts adversely on imports flow of GCC country, but no significant effect is revealed on exports flow. No significant impact of common language has been found in either imports or exports.

The problem of CSD has been addressed further in Driscoll-Kraay estimates that provide the spatial correlation consistent standard error estimator (Table 6). We perform pooled OLS regression with Driscoll-Kraay standard errors, which are heteroskedasticity consistent and robust to general forms of cross-sectional and 
temporal dependence. We also perform fixed-effects regression with DriscollKraay standard errors, which are robust to general forms of cross-sectional and temporal dependence. In these two cases, the error structure of import, export and trade panels is assumed to be heteroskedastic, autocorrelated and possibly correlated between the panels. Since all the three panels in our study suffer from heteroskedasticity, autocorrelation and CSD, Driscoll-Kraay estimates provide consistent estimates of GCC coefficient of our gravity equation (Table 6). In imports panel we obtain statistically significant GCC coefficient in all the estimates, but in exports panel we get significant GCC in FEM. In trade panel it turns out to be significant in both the estimates.

What is of interest in this study is GCC variable in which the coefficient of it turned to be positive and significant in most of the valid estimators, which is in line

Table 6. Estimation Corrected for Cross-Sectional Dependence

\begin{tabular}{|c|c|c|c|c|c|c|}
\hline & \multicolumn{2}{|c|}{ IMPORTS } & \multicolumn{2}{|c|}{ EXPORTS } & \multicolumn{2}{|c|}{ TRADE } \\
\hline & $\begin{array}{c}\text { Driscoll- } \\
\text { Kraay FEM } \\
\text { (Robust SE) }\end{array}$ & $\begin{array}{c}\text { Driscoll- } \\
\text { Kraay Pooled } \\
\text { OLS }\end{array}$ & $\begin{array}{c}\text { Driscoll- } \\
\text { Kraay FEM } \\
\text { (Robust SE) }\end{array}$ & $\begin{array}{c}\text { Driscoll- } \\
\text { Kraay Pooled } \\
\text { OLS }\end{array}$ & $\begin{array}{c}\text { Driscoll- } \\
\text { Kraay FEM } \\
\text { (Robust SE) }\end{array}$ & $\begin{array}{c}\text { Driscoll- } \\
\text { Kraay Pooled } \\
\text { OLS }\end{array}$ \\
\hline $\ln Y_{i}$ & $\begin{array}{c}0.508 \\
(0.344)\end{array}$ & $\begin{array}{c}1.267 \\
(0.043)\end{array}$ & $\begin{array}{c}0.261 \\
(0.216)\end{array}$ & $\begin{array}{c}0.803^{* * *} \\
(0.021)\end{array}$ & $\begin{array}{c}0.349 \\
(0.248)\end{array}$ & $\begin{array}{c}0.987^{* * *} \\
(0.025)\end{array}$ \\
\hline $\ln Y_{j}$ & $\begin{array}{l}1.849^{* * *} \\
(0.193)\end{array}$ & $\begin{array}{c}0.699^{* * *} \\
(0.071)\end{array}$ & $\begin{array}{l}1.300^{* * *} \\
(0.200)\end{array}$ & $\begin{array}{l}0.711^{* * * *} \\
(0.022)\end{array}$ & $\begin{array}{c}1.567^{* * *} \\
(0.171)\end{array}$ & $\begin{array}{c}0.703^{* * *} \\
(0.040)\end{array}$ \\
\hline lnDist & $\begin{array}{c}-7.110^{* * *} \\
(0.696)\end{array}$ & $\begin{array}{l}-0.655 \\
(0.139)\end{array}$ & $\begin{array}{c}-4.438^{* * *} \\
(0.387)\end{array}$ & $\begin{array}{c}-0.275^{* * *} \\
(0.048)\end{array}$ & $\begin{array}{c}-5.621^{* * *} \\
(0.398)\end{array}$ & $\begin{array}{c}-0.400^{* * *} \\
(0.077)\end{array}$ \\
\hline $\ln R E R$ & $\begin{array}{c}-0.559^{* * *} \\
(0.249)\end{array}$ & $\begin{array}{c}-0.171^{* * *} \\
(0.030)\end{array}$ & $\begin{array}{c}-0.430^{* * *} \\
(0.055)\end{array}$ & $\begin{array}{c}-0.019 \\
(0.009)\end{array}$ & $\begin{array}{c}-0.488^{* * *} \\
(0.088)\end{array}$ & $\begin{array}{c}-0.077^{* * *} \\
(0.016)\end{array}$ \\
\hline Adj & & $\begin{array}{l}-0.503^{*} \\
(0.471)\end{array}$ & & $\begin{array}{c}-0.587^{* * *} \\
(0.204)\end{array}$ & & $\begin{array}{c}-0.509^{* *} \\
(0.323)\end{array}$ \\
\hline Lang & & $\begin{array}{l}-0.909^{*} \\
(0.726)\end{array}$ & & $\begin{array}{l}-0.116 \\
(0.215)\end{array}$ & & $\begin{array}{l}-0.435 \\
(0.255)\end{array}$ \\
\hline$G C C$ & $\begin{array}{c}0.467^{* * *} \\
(0.160)\end{array}$ & $\begin{array}{l}1.190^{* * *} \\
(0.392)\end{array}$ & $\begin{array}{c}0.727^{* * *} \\
(0.150)\end{array}$ & $\begin{array}{c}0.513 \\
(0.184)\end{array}$ & $\begin{array}{l}0.611^{* * *} \\
(0.139)\end{array}$ & $\begin{array}{c}0.834^{* * *} \\
(0.133)\end{array}$ \\
\hline Constant & & $\begin{array}{c}-38.716^{* * *} \\
(2.087)\end{array}$ & & $\begin{array}{c}-30.708^{* * *} \\
(0.592)\end{array}$ & & $\begin{array}{c}-33.993^{* * *} \\
(0.980)\end{array}$ \\
\hline $\begin{array}{l}\text { Time Peri } \\
2008\end{array}$ & od: 1980- & & & & & \\
\hline $\mathrm{R}^{2}$ & 0.295 & 0.488 & 0.366 & 0.650 & 0.305 & 0.538 \\
\hline $\mathrm{F}$ & $23119.29^{* * * *}$ & $1536.86^{* * *}$ & $7503.75^{* * *}$ & $11469.95^{* * *}$ & $10430.59^{* * *}$ & $2832.05^{* * *}$ \\
\hline
\end{tabular}

Note: Numbers in the parentheses are standard errors. ${ }^{* * *},{ }^{* *}$ and ${ }^{*}$ indicate that estimated coefficients are significant at 1,5 and $10 \%$ levels respectively. 
Table 7. Effect of GCC on Trade (\%)

\begin{tabular}{lccc}
\hline Estimator & IMPORTS & EXPORTS & TRADE \\
\hline FEM & 106.89 & $(59.52)$ & 84.23 \\
FEM [AR(1) and Heteroskedasticity] & -33.83 & $(-25.47)$ & -27.89 \\
Poisson Pseudo-ML, Fixed Effects & 34.99 & $(1.92)$ & 12.75 \\
Gamma Poisson Pseudo-ML & $(285.74)$ & $(177.04)$ & 208.95 \\
$\begin{array}{l}\text { Prais-Winsten Common AR(1) with Heteroske- } \\
\text { dasticity }\end{array}$ & 60.48 & 66.03 & 60.16 \\
$\begin{array}{l}\text { Prais-Winsten Panel-Specific AR(1) with Het- } \\
\text { eroskedasticity }\end{array}$ & 56.83 & 67.36 & 64.05 \\
$\begin{array}{l}\text { Driscoll-Kraay FEM (Robust SE) } \\
\text { Driscoll-Kraay Pooled OLS }\end{array}$ & 59.52 & 106.89 & 84.23 \\
\hline
\end{tabular}

*Values in the parentheses indicate that these are calculated from statistically insignificant coefficients.

with our prior expectation and supports the previous empirical findings. It indicates that the membership of the group (GCC) has had a substantial trade enhancing impact.

\section{B. Realization of trade potential}

The Maximum Likelihood (ML) estimates of Equation (5) have been presented in Table 5 for both the Time-Invariant (TI) and the Time-Varying Decay (TVD) models. The results help choose between two models based on the sign and significance of the coefficients from diagnostic tests.

On the imports side, $Y_{i t}$ and $Y_{j t}$ turn out to be positive as expected in exports and trade model. The negative sign of Dist $t_{i j}$ is negative and significant for TI but insignificant for TVD model for trade. RER has always been negative and significant. $A d j_{i j}$ take the expected sign with significance at $1 \%$ level, which indicates that common border has highly significant trade enhancing impact for GCC. Common language is found to be significantly imports-enhancing in TVD model.

The estimated $\mu$ also turns out to be statistically significant in both import and export panels, which indicates that a truncated normal distribution fits the $u_{i j}$ better than the half-normal distribution. Also, positive and significant $\eta$ for all the panels indicates that beyond and behind the border constraints for imports and exports of CGG countries are decreasing over time, hence TVD model provides correct estimation of the model. In addition, the estimated $\gamma$ turned out to be significant for all the panels. It means that the decomposition of the error term into $u$ and $v$ is 
valid for the present data sets and the deviation of actual trade from the potential is due to behind and beyond the border constraints, and not merely by random chances.

After the time invariant and time varying decay estimation of import and export panels, the $\gamma$ coefficient turns out to be significantly different from zero. As $\gamma$ lies between 0 and 1 , the optimization is parameterized with respect to its inverse logit (ilgt $\gamma$ ). The coefficients of $i$ lgt $\gamma$ are significant at $1 \%$ level in imports and trade panels. The large and significant $\gamma$ coefficients in both import and trade panels

Table 7. Maximum Likelihood Estimates

\begin{tabular}{|c|c|c|c|c|c|c|}
\hline & \multicolumn{2}{|c|}{ IMPORTS } & \multicolumn{2}{|c|}{ EXPORTS } & \multicolumn{2}{|c|}{ TRADE } \\
\hline & TI & TVD & TI & TVD & $\mathrm{TI}$ & TVD \\
\hline $\ln Y_{i}$ & $\begin{array}{l}0.384^{* * *} \\
(0.044)\end{array}$ & $\begin{array}{l}-0.004 \\
(0.047)\end{array}$ & $\begin{array}{l}0.883^{* * *} \\
(0.097)\end{array}$ & $\begin{array}{l}0.589^{* * *} \\
(0.086)\end{array}$ & $\begin{array}{l}0.591^{* * *} \\
(0.048)\end{array}$ & $\begin{array}{l}0.297^{* * *} \\
(0.055)\end{array}$ \\
\hline $\ln Y_{j}$ & $\begin{array}{l}1.101^{* * *} \\
(0.047)\end{array}$ & $\begin{array}{l}0.292^{* * *} \\
(0.066)\end{array}$ & $\begin{array}{l}1.367^{* * *} \\
(0.098)\end{array}$ & $\begin{array}{l}0.398^{* * *} \\
(0.117)\end{array}$ & $\begin{array}{l}1.218^{* * *} \\
(0.050)\end{array}$ & $\begin{array}{l}0.484^{* * *} \\
(0.067)\end{array}$ \\
\hline lnDist & $\begin{array}{c}-0.574^{* * *} \\
(0.218)\end{array}$ & $\begin{array}{c}0.503^{*} \\
(0.259)\end{array}$ & $\begin{array}{c}-1.021^{* * *} \\
(0.369)\end{array}$ & $\begin{array}{c}-0.659^{* *} \\
(0.324)\end{array}$ & $\begin{array}{c}-0.758^{* * *} \\
(0.197)\end{array}$ & $\begin{array}{l}-0.123 \\
(0.186)\end{array}$ \\
\hline $\operatorname{lnRER}$ & $\begin{array}{c}-0.155^{* * *} \\
(0.038)\end{array}$ & $\begin{array}{c}-0.324^{* * *} \\
(0.047)\end{array}$ & $\begin{array}{c}-0.253^{* * *} \\
(0.063)\end{array}$ & $\begin{array}{c}-0.390^{* * *} \\
(0.057)\end{array}$ & $\begin{array}{c}-0.170^{* * *} \\
(0.034)\end{array}$ & $\begin{array}{c}-0.264^{* * *} \\
(0.036)\end{array}$ \\
\hline Adj & $\begin{array}{l}-0.197 \\
(0.428)\end{array}$ & $\begin{array}{l}2.596^{* * *} \\
(0.546)\end{array}$ & $\begin{array}{l}-0.348 \\
(0.572)\end{array}$ & $\begin{array}{c}2.190^{* * *} \\
(0.568)\end{array}$ & $\begin{array}{l}-0.234 \\
(0.348)\end{array}$ & $\begin{array}{l}1.986^{* * *} \\
(0.365)\end{array}$ \\
\hline Lang & $\begin{array}{c}0.255 \\
(0.593)\end{array}$ & $\begin{array}{l}1.674^{* *} \\
(0.702)\end{array}$ & $\begin{array}{l}1.090 \\
(1.004)\end{array}$ & $\begin{array}{l}-1.372 \\
(0.912)\end{array}$ & $\begin{array}{c}0.571 \\
(0.533)\end{array}$ & $\begin{array}{c}0.047 \\
(0.504)\end{array}$ \\
\hline$G C C$ & $\begin{array}{c}0.742^{* * *} \\
(0.151)\end{array}$ & $\begin{array}{c}0.096 \\
(0.146)\end{array}$ & $\begin{array}{c}0.514^{*} \\
(0.289)\end{array}$ & $\begin{array}{c}0.091 \\
(0.285)\end{array}$ & $\begin{array}{c}0.638^{* * *} \\
(0.155)\end{array}$ & $\begin{array}{c}0.162 \\
(0.155)\end{array}$ \\
\hline Constant & $\begin{array}{c}-24.952^{* * *} \\
(2.362)\end{array}$ & $\begin{array}{l}-1.475 \\
(2.918)\end{array}$ & $\begin{array}{c}-39.448^{* * *} \\
(4.106)\end{array}$ & $\begin{array}{c}-10.923^{* *} \\
(4.626)\end{array}$ & $\begin{array}{c}-30.904^{* * *} \\
(2.531)\end{array}$ & $\begin{array}{c}-10.335^{* * *} \\
(2.371)\end{array}$ \\
\hline Cross-Sectional Unit & 120 & 120 & 120 & 120 & 240 & 240 \\
\hline $\begin{array}{l}\text { No of Observations } \\
\text { Time Period: } \\
\text { 1980-2008 }\end{array}$ & 3480 & 3480 & 3480 & 3480 & 6960 & 6960 \\
\hline $\begin{array}{l}\mu \\
\eta\end{array}$ & $3.934^{* * *}$ & $\begin{array}{l}5.473^{* * *} \\
0.009^{* * *}\end{array}$ & $5.374^{* * *}$ & $\begin{array}{l}3.146^{* * *} \\
0.018^{* * *}\end{array}$ & $4.730^{* * *}$ & $\begin{array}{l}3.552^{* * *} \\
0.013^{* * *}\end{array}$ \\
\hline $\ln \sigma^{2}$ & $0.558^{* * *}$ & $0.639^{* * *}$ & $1.356^{* * *}$ & $1.212^{* * *}$ & $0.968^{* * *}$ & $0.926^{* * *}$ \\
\hline$\gamma$ & $0.746^{* * *}$ & $0.880^{* * *}$ & $0.575^{* * *}$ & $0.534^{* * *}$ & $0.641^{* * *}$ & $0.649^{* * *}$ \\
\hline ilgt $\tilde{a}$ & $1.081^{* * *}$ & $1.999^{* * *}$ & 0.303 & 0.137 & $0.580^{* * *}$ & $0.618^{* * *}$ \\
\hline Wald $\chi^{2}$ & $1362.99^{* * *}$ & $108.34^{* * *}$ & $649.78^{* * *}$ & $162.65^{* * *}$ & $1706.86^{* * *}$ & $280.56^{* * *}$ \\
\hline Log Likelihood & -2863.18 & -2706.81 & -3050.13 & -3013.16 & -6392.54 & -6277.12 \\
\hline
\end{tabular}


indicate that the influence of such country-specific factors explain a large proportion of mean total variation $\left(\sigma^{2}\right)$ of the models. The estimated $\gamma$ explains $88 \%$ of total variation in imports panel, which captures the influence beyond the constraints on imports. For exports, behind the border constraints explain around $53 \%$ of total variation. That is, beyond the border constraints contribute a larger and significant proportion to the variation in the gaps between potential and actual exports of GCC members. When considered the trade model, these constraints jointly explain $65 \%$ variation in total trade.

Trade potential measure provides useful insight to examine the scope of the highest possible trade expansion between the bilateral partners. In the conventional gravity model, trade potential or the performance of bilateral trade flow can be measured using the mean prediction (Baldwin, 1994). As opposed to such exercise, an estimate of the highest potential has been worked out from the linear predictions of the estimated regression coefficients of the trade frontier from Equation (5).

Following Kalirajan (1999), the realization of trade potential has been calculated for each of the member countries and depicted in Figure 2. It reveals that on average Bahrain realized only around $60 \%$ of its export potential to GCC during the sample period, while Kuwait, Oman and Qatar realized only about $45 \%$. Saudi Arabia and UAE realized slightly higher than $60 \%$. Conversely, Bahrain, Kuwait and Oman realized only about $45 \%$ of their import potential from GCC, while Qatar realized half of its import potential. Saudi Arabia and UAE realized little higher than $50 \%$ of its import potential.

The results imply an important fact of trading regimes prevailing among the GCC members - the unobserved import policies and institutional rigidities are perhaps more restrictive towards this region than that of exports except for the members. This is indicated by the higher magnitude of total variation in import due to beyond the border constraints than the constraints of exports. Therefore, this

Figure 2. Realization of Exports (left) and Imports (right) Potential (\%)
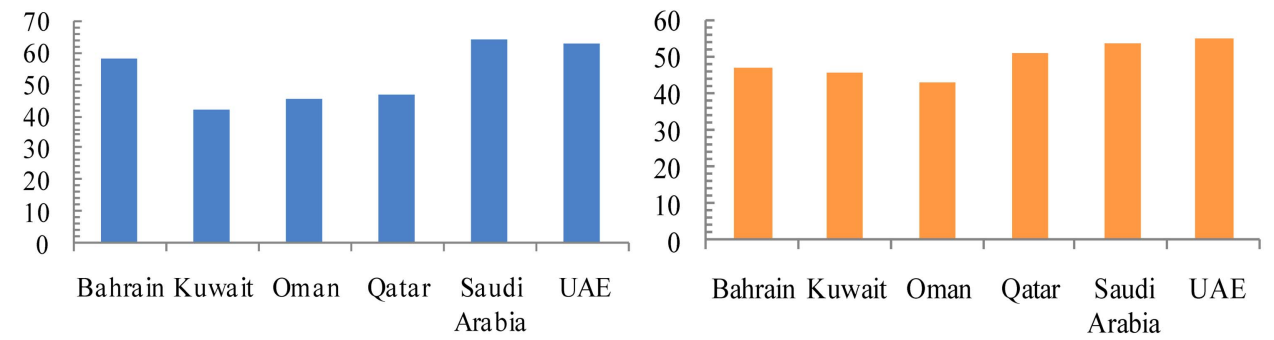
resulted in higher average realization of exports potential than that of imports.

\section{Conclusions}

In application of gravity model to examine bilateral trade, the panel data may suffer from contemporaneous correlation along with serial correlation and heteroscedasticity, leading to inefficient as well as inconsistent estimates. Examining and addressing these problems is ignored in the literature. In asessesing trade enhancing impact of the GCC on its members by employing a standard augmented gravity model, we reveal that both the import and export panels suffer from contemporaneous correlation, heteroskedasticity and serial correlation. These problems have been tackled by Prais-Winsten regression and Driscoll-Kraay estimators, which provide panels-corrected and robust standard errors for the regression coefficients. The results in genral suggest that most of the variables take desired signs and turn out to be statistically significant. The principal finding shows that the trade enhancing effect of the bloc is significant. Stochastic frontier gravity models has been applied to examine the realization of trade potential amongst the member countries. The non-negative error component explains most of the total variation, which captures behind and beyond the border constraints. It indicates that stochastic frontier specification was correct for estimating the gravity model. The estimation of individual and mean trade potential suggests that GCC countries can substantially expand both imports and exports among themselves if they can minimise various behind and beyond the border constraints, which needs for addressing bilateral trade policies at the outset. Thus, the process of a meaningful economic integration within this bloc should be aimed primarily at policy liberalization, policy reforms and policy coordination amongst member countries.

Received 15 October 2010, Revised 22 February 2011, Accepted 8 April 2011

\section{References}

Al-Atrash, H. and Yousef, T. (2000), Intra-Arab Trade: Is It Too Little? IMF Working Paper 00/10, Washington, DC: International Monetary Fund.

Anderson, J. and van Wincoop, E. (2004), Trade Costs, Working Paper \# 10480, National Bureau of Economic Research, Massachusetts.

Anderson, J. E. and van Wincoop, E. (2003), Gravity with Gravitas: A Solution to the Border Puzzle, American Economic Review, 93, 170-192. 
Armstrong, S., Drysdale, P. and Kalirajan, K. (2008), Asian Trade Structures and Trade Potential: An Initial Analysis of South and East Asian Trade, EABER Working Paper 32, Australian National University, Canberra.

Athukorala, P. (2009), The Rise of China and East Asian Export Performance: Is the Crowding-Out Fear Warranted?, World Economy, 32, 234-266.

Baier, S.L. and Bergstrand, J.H. (2007), Do Free Trade Agreements Actually Increase Members' International Trade?" Journal of International Economics, 71, 72-95.

Baier, S.L., Bergstrand, J.H. and Vidal, E. (2007), Free Trade Agreements in the Americas: Are the Trade Effects Larger than Anticipated?, World Economy, 30, 1347-1377.

Baldwin, R.E. (1994), Towards an Integrated Europe, CEPR, London.

Baldwin, R.E. and Taglioni, D. (2006), Gravity for Dummies and Dummies for Gravity Equations", Working Paper 12516, National Bureau of Economic Research, Massachusetts. Baltagi, B.H. and Wu, P.X. (1999), Unequally Spaced Panel Data Regressions with AR(1) Disturbances. Econometric Theory, 15, 814-823.

Baltagi, B.H., Egger, P. and Pfaffermayr, M. (2003), A Generalized Design for Bilateral Trade Flow Models, Economics Letters, 80, 391-397.

Bayoumi, T. and Eichengreen, B. (1998), Is Regionalism Simply a Diversion? Evidence from the Evolution of the EC and EFTA, In T. Ito and A. Krueger (eds.), Regionalism versus Multilateral Trade Arrangements, University of Chicago Press, Chicago.

Bhagwati, J. (2008), Termites in the Trading System: How Preferential Agreements Undermine Free Trade, Oxford University Press, Oxford.

Bhagwati, J. and Panagariya, A. (1996), Preferential Trading Areas: Strangers, Friends or Foes?" In J. Bhagwati, and A. Panagariya (eds.), The Economics of Preferential Trade Agreements, American Enterprise Institute Press, Washington, DC.

Boughanmi, H. (2008), The Trade Potential of the Arab Gulf Cooperation Countries (GCC): A Gravity Model Approach, Journal of Economic Integration, 23, 42-56.

Boughanmi, H., Shidhani, J.A., Mbaga, M. Kotagama, H. (2009), The Effects of Regional Trade Arrangements on Agri-Food Trade: An Application of the Gravity Modeling Approach to the Arab Gulf Cooperation Council (GCC) Countries, Review of Middle East Economics and Finance, 5(3), Art3.

Bolbol, A. and Fatheldin, A. (2005), Intra-Arab Exports and Direct Investment: An Empirical Analysis, AMF Economic Papers, Arab Monetary Fund, Abu Dhabi.

Breusch, T.S. and Pagan, A.R. (1980), The Lagrange Multiplier Test and its Applications to Model Specification in Econometrics, Review of Economic Studies, 47, 239-253.

Brun, J., Carrère, C., Guillaumont, P. and Melo, J. (2005), Has Distance Died? Evidence from a Panel Gravity Model, World Bank Economic Review, 19, 99-120.

Bussière, M. and Schnatz, B. (2009), Evaluating China's Integration in World Trade with a Gravity Model Based Benchmark, Open Economies Review, 20, 85-111.

Bussière, M., Fidrmuc, J. and Schnatz, B. (2008), EU Enlargement and Trade Integration: Lessons from a Gravity Model, Review of Development Economics, 12, 562-576.

Carrère, C. (2006), Revisiting the Effects of Regional Trade Agreements on Trade Flows with Proper Specification of the Gravity Model, European Economic Review, 50, 
$223-247$.

Cipollina, M. and Salvatici, L. (2010), Reciprocal Trade Agreements in Gravity Models: A Meta-Analysis, Review of International Economics, 18, 63-80.

Darrata, A.F. and Al-Shamsi, F.S. (2005), On the Path of Integration in the Gulf region, Applied Economics, 37, 1055-1062.

Deardorff, A.V. (1998), Determinants of Bilateral Trade: Does Gravity Work in a Neoclassical World?, In J.A. Frankel (ed.), The Regionalization of the World Economy, University of Chicago Press: Chicago.

Disdier, A. and Head, K. (2008), The Puzzling Persistence of the Distance Effect on Bilateral Trade, Review of Economics and Statistics, 90, 37-48.

Driscoll, J.C. and Kraay, A.C. (1998), Consistent Covariance Matrix Estimation with Spatially Dependent Panel Data, Review of Economics and Statistics, 80, 549-560.

Drysdale, P. and Garnaut, R. (1982), Trade Intensities and the Analysis of Bilateral Trade Flows in a Many-country World: A Survey, Hitotsubashi Journal of Economics, 22(2), 62-84.

Eaton, J. and Kortum, S. (2002), Technology, Geography, and Trade, Econometrica, 70, 1741-1779.

Egger, P. (2002), An Econometric View on the Estimation of Gravity Models and the Calculation of Trade Potentials, World Economy, 25, 297-312.

Elhorst, J.P. (2003), Specification and Estimation of Spatial Panel Data Models, International Regional Science Review, 26, 244-268.

Feenstra, R. (2002), Border Effects and the Gravity Equation: Consistent Methods for Estimation, Scottish Journal of Political Economy, 49, 491-506.

Feenstra, R., Markusen, J. and Rose, A. (2001), Using the Gravity Equation to Differentiate among Alternative Theories of Trade, Canadian Journal of Economics, 34, 430-447.

Frankel, J.A., Stein, E. and Wei, S-J. (1995), Trading Blocs and the Americas: The Natural, the Unnatural, and the Super-Natural, Journal of Development Economics, 47, 61-95.

Gil-Pareja, S., Llorca-Vivero, R. Martínez-Serrano, J.A. and Oliver-Alonso, J. (2005), The Border Effect in Spain, World Economy, 28, 1617-1631.

Halvorsen, R. and Palmquist, R. (1980), The Interpretation of Dummy Variables in Semilogarithmic Equations, American Economic Review, 70, 474-475.

Haveman, J. and Hummels, D. (2004), Alternative Hypotheses and the Volume of Trade: The Gravity Equation and the Extent of Specialization, Canadian Journal of Economics, 37, 199-218.

Helpman, E., Melitz, M. and Rubinstein, Y. (2008), Estimating Trade Flows: Trading Partners and Trading Volumes, Quarterly Journal of Economics, 123, 441-487.

Hutchinson, W.K. (2002), Does Ease of Communication Increase Trade? Commonality of Language and Bilateral Trade, Scottish Journal of Political Economy, 49, 544-556.

Kabir, M. and Salim, R. (2010), Can Gravity Model Explain BIMSTEC's Trade? Journal of Economic Integration, 25(1), 144-166. 
Kabir, M. (2010), Trade Response to Preferential Liberalization: Evidence from Some Emerging Asian Countries, Lambert Academic Publishing, Germany.

Kalirajan, K. (1999), Stochastic Varying Coefficients Gravity Model: An Application in Trade Analysis, Journal of Applied Statistics, 26, 185-193.

Kalirajan, K. and Singh, K. (2008), A Comparative Analysis of China's and India's Recent Export Performances, Asian Economic Papers, 7, 1-28.

Kandogan, Y. (2008), Consistent Estimates of Regional Blocs' Trade Effects, Review of International Economics, 16, 301-314.

Kapetanios, G. (2011), Panels with Non-Stationary Multifactor Error Structures, Journal of Econometrics, 160, 326-348.

Kelejian, H.H., and Prucha, I.R. (2007), HAC Estimation in a Spatial Framework, Journal of Econometrics, 140, 131-154.

Keller, W. and Shiue, C.H. (2007), The Origin of Spatial Interaction, Journal of Econometrics, 140, 304-332.

Kézdi, G. (2004), Robust Standard Error Estimation in Fixed Effects Panel Models, Hungarian Statistical Review, 9, 95-116 (Special English Volume).

Kim, M.S. and Sun, Y. (2011), Spatial Heteroskedasticity and Autocorrelation Consistent Estimation of Covariance Matrix, Journal of Econometrics, 160, 349-371.

Kirkpatrick. C. and Watanabe, M. (2005), Regional Trade in Sub-Saharan Africa: An Analysis of East African Trade Cooperation, 1970-2001, Manchester School, 73, 141-164.

Krugman, P.R. (1991), The Move toward Free Trade Zones, Proceedings, Federal Reserve Bank of Kansas City, Kansas, 7-41.

Laabas, B. and Limam, I. (2002), Are GCC Countries Ready for Currency Union?, API Working Paper 0203, Arab Planning Institute, Kuwait.

Lee, H. and Park, I. (2007), In Search of Optimised Regional Trade Agreements and Applications to East Asia, World Economy, 30, 783-806.

Lee, J. and Shin, K. (2006), Does Regionalism Lead to More Global Trade Integration in East Asia?, North American Journal of Economics and Finance, 17, 283-301.

Martinez-Zarzoso, I. and Nowak-Lehmann, F. (2003), Augmented Gravity Model: An Empirical Application to Mercosur-European Union Trade Flows, Journal of Applied Economics, 6, 291-316

Mehanna, R.-A. (2003), Do Politics and Culture Affect Middle East Trade? Evidence from the Gravity Model, Review of Middle East Economics and Finance, 1, 155-170.

Melitz, J. (2008), Language and Foreign Trade, European Economic Review, 52, 667-699. Nugent, J. (2002), Why Does MENA Trade So Little?, Background Paper to the MENA Development Report 2003. The World Bank, Washington D.C.

Papazoglou, C., Pentecost, E.J. and Marques, H. (2006), A Gravity Model Forecast of the Potential Trade Effects of EU Enlargement: Lessons from 2004 and Path-dependency in Integration, World Economy, 29, 1077-1089.

Pesaran, M.H. (2004), General Diagnostic Tests for Cross Section Dependence in Panels, Cambridge Working Papers in Economics 0435, University of Cambridge, Cambridge. 
Pöyhönen, P. (1963), Toward a General Theory of International Trade, Ekonomiska Samfundets Tidskrift, 1963(2), 69-77.

Pulliainen, K. (1963), A World Trade Study: An Econometric Study of the Pattern of the Commodity Flows in International Trade, 1948-60, Ekonomiska Samfundets Tidskrift, 1963(2), 78-91.

Santos Silva, J. M. C. and Tenreyro, S. (2006), The Log of Gravity, Review of Economics and Statistics, 88, 641-658.

Serlenga, L. and Shin, Y. (2007), Gravity Models of Intra-EU Trade: Application of the CCEP-HT Estimation in Heterogeneous Panels with Unobserved Common TimeSpecific Factors, Journal of Applied Econometrics, 22, 361-381.

Soloaga, I. and Winters, L.A. (2001), Regionalism in Nineties: What Effect on Trade?, North American Journal of Economics and Finance, 12, 1-29.

Stock, J.H. and Watson, M.W. (2006), Heteroskedasticity-Robust Standard Errors for Fixed Effects Panel Data Regression, Technical Working Paper 323, National Bureau of Economic Research, Massachusetts.

Tinbergen, J. (1962), An Analysis of World Trade Flows, In J. Tinbergen (ed.), Shaping the World Economy, The Twentieth Century Fund, New York.

Westerlund, J. and Wilhelmsson, F. (2011), Estimating the Gravity Model without Gravity Using Panel Data, Applied Economics, 43, 641-649.

Wolf, H.C. (2000), International Home Bias in Trade, Review of Economics and Statistics, 82, 555-563. 